\title{
SYNTHESIS AND PRELIMINARY MOLECULAR DOCKING STUDIES OF NOVEL ETHYL-GLYCINATE AMIDE DERIVATIVES
}

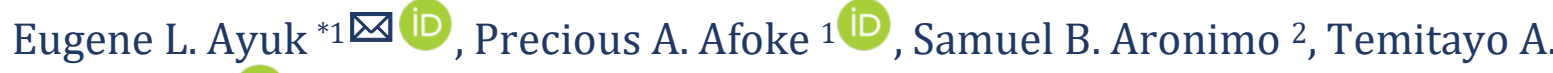 \\ Olowolafe ${ }^{3}$ iD \\ ${ }^{* 1}$ Department of Chemical Sciences Godfrey Okoye University, P.M.B 01014, Thinkers Corner \\ Enugu, Nigeria Thinkers Corner, Enugu, Nigeria \\ 2 Department of Chemistry Kogi State College of Education (Tech) Kabba, Kogi State, Nigeria \\ ${ }^{3}$ Ladoke Akintola University of Technology, Ogbomoso, Oyo State, Nigeria
}

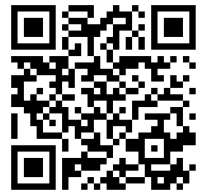

DOI: https://doi.org/10.29121/granthaalayah.v8.i9.2020.338

Article Type: Research Article

Article Citation: Eugene L. Ayuk, Precious A. Afoke, Samuel B. Aronimo, and Temitayo A. Olowolafe. (2020). SYNTHESIS AND PRELIMINARY MOLECULAR DOCKING STUDIES OF NOVEL ETHYL-GLYCINATE AMIDE DERIVATIVES. International Journal of Research -GRANTHAALAYAH, 8(9), 368-382.

https://doi.org/10.29121/granthaa layah.v8.i9.2020.338

Received Date: 1 June 2020

Accepted Date: 30 September 2020

Keywords:

Glycine

Esterification

Molecular Docking

Celecoxib and Rofecoxib

Inhibitory Activity

\section{ABSTRACT}

Ethyl glycinate was synthesized by the Fischer esterification protocol, and its amide derivatives; 2-amino- $N$-(nitrophenyl)acetamide 31, 2amino- $N$-(6-methylpyridin-2-yl) acetamide 33, $N, N^{\prime}-(1,4-$ phenylene)bis(2-aminoacetamide) $35, \quad N, N^{\prime}$-(6-chloropyrimidine-2,4-diyl)bis-(2aminoacetamide) 37, and 2,4-(diamino- $N{ }^{\prime} N-6$ hydroxypyrimidyl)acetamide 39 respectively were obtained by coupling reactions of 4-nitroaniline, 2-amino-6-methylpyridine, 1,4-diamino-N,N'benzene, 2,6-diamino-4-chloropyrimidine and 2,4-diamino-6hydroxypyrimidine respectively with ethyl glycinate. These compounds were characterized on the basis of their melting points, UV-Visible, IR, ${ }^{1} \mathrm{HNMR}$ and ${ }^{13} \mathrm{CNMR}$ spectroscopic analyses. The results obtained from the spectra were consistence with the assigned structures of the compounds. The synthesized compounds were subjected to molecular docking with a target protein, $1 \mathrm{CVU}$ to compare their binding energies with celecoxib and rofecoxib which are standard drugs that inhibit COX2 enzyme. From the docking results, the binding energies values of the above synthesized compounds are $-5.8 \mathrm{kJmol}^{-1},-6.2 \mathrm{kJmol}^{-1},-7.2 \mathrm{kJmol}^{-1},-7.4 \mathrm{kJmol}^{-1}$ and -7.6 $\mathrm{kJmol}^{-1}$ respectively. Compound 39 showed the highest binding energy of $7.6 \mathrm{kJmol}^{-1}$, close to celecoxib and rofecoxib with binding energy values of $-8.0 \mathrm{kJmol}^{-1}$ and $-8.2 \mathrm{kJmol}^{-1}$ respectively. This result indicates that compound 39 possess some level of inhibitory activity against COX2.

\section{INTRODUCTION}

Amino acids are molecules containing both amino and carboxylic acid groups. There are basically twenty in number namely; glycine $\mathbf{1}$, alanine $\mathbf{2}$, serine3, threonine $\mathbf{4}$, cysteine $\mathbf{5}$, valine $\mathbf{6}$, leucine $\mathbf{7}$, isoleucine $\mathbf{8}$, methionine $\mathbf{9}$, proline10, phenylalanine 11, tyrosine 12, tryptophan 13, aspartic acid 14, glutamic acid 15, asparagine 16, glutamine 17, histidine 18, lysine 19, arginine 20, and of all these, glycine 1 is the simplest, Young (1994). Out of these, nine of them are classified as essential amino acids, because they cannot be synthesized by the body and are therefore required to be taken in diets namely; histidine, leucine, isoleucine, lysine, methionine, phenylalanine, threonine, tryptophan, and valine according to Dietary Reference Intakes (2014). The non-essential amino acids can

(C) 2020 The Author(s). This is an open access article distributed under the terms of the Creative Commons Attribution License, which permits unrestricted use, distribution, and reproduction in any medium, provided the original author and source are credited. 
be synthesized in the body and they include alanine, aspartic acid, asparagine, glutamic acid, serine, while arginine, cysteine, glycine, glutamine, proline, and tyrosine are classified as conditionally essential amino acids, meaning their synthesis can be limited under special pathophysiological conditions, such as prematurity in the infant or individuals in severe catabolic distress, Young (1994) and Dietary Reference Intakes (2014).

Amino acids are the building blocks for protein synthesis, through the formation of peptides linkages according to Wilson (2016). The structures of the twenty (20) alpha-amino acids are shown in fig 1 below.

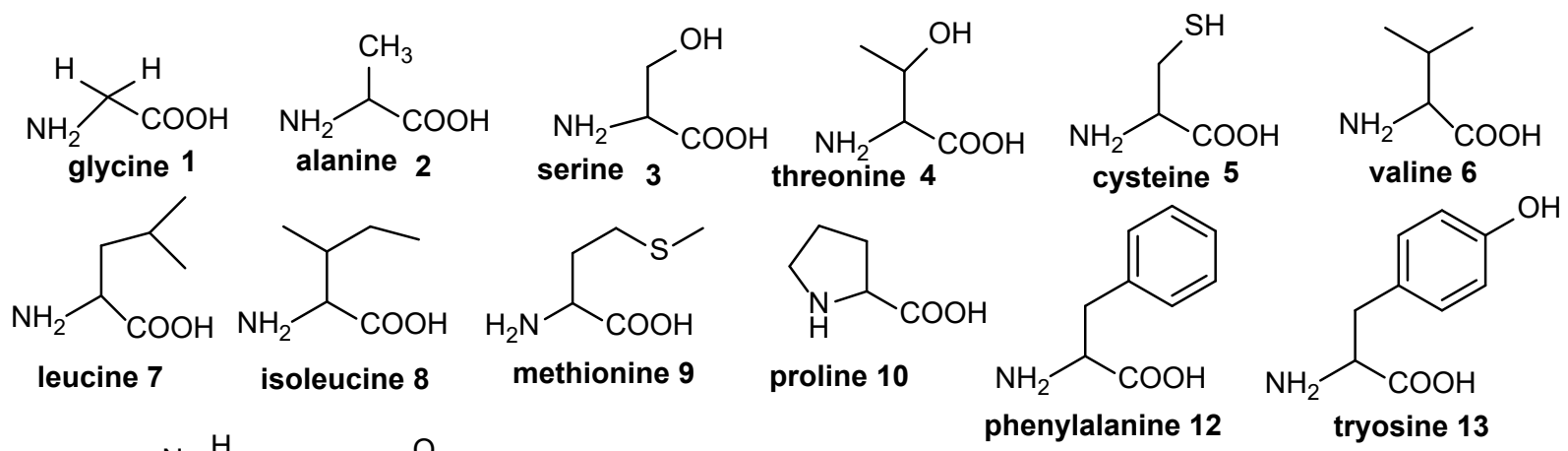<smiles>NC(Cc1c[nH]c2ccccc12)C(=O)O</smiles>

tryptophan 13<smiles>NCCC(=O)O</smiles><smiles>NC(CC(=O)O)C(=O)O</smiles>

aspartic acid 14

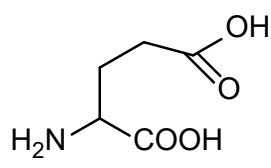

glutamic acid 15<smiles>NC(=O)CC(N)=O</smiles>

asparagine 16<smiles>NC(=O)CCC(N)C(=O)O</smiles>

glutamine 17

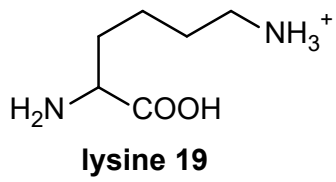<smiles>NC(=[NH2+])CCCCC(N)C(=O)O</smiles>

Figure 1: Structures and names of the 20 amino acids

Glycine $\mathbf{1}$ is the simplest and a conditionally essential amino acid; its chemical formula is $\mathrm{C}_{2} \mathrm{H}_{5} \mathrm{NO}_{2}$. It is a white solid with density of $1.607 \mathrm{~g} / \mathrm{mol}$. It is soluble in pyridine, sparingly soluble in ethanol and insoluble in ether. It was first produced by a French chemist, H. Braconnot from acid hydrolysis of protein in 1820, according to Wang et al (2013). It has a sweet taste like glucose and can also be produced by alkaline hydrolysis of meat and gelatin with potassium hydroxide. Because of its simplicity, it has only one form, unlike other amino acids that possess the $L$ and D isomers.

$\mathrm{Wu}(2009)$ reported that glycine supports healthy kidney and liver function as well as the nervous system and serves as a major constituent in extracellular structural proteins (collagen and elastin) in animals. Although glycine has been traditionally classified as a "nutritionally conditionally essential amino acid" for mammals (including humans, pigs and rodents) due to the presence of its endogenous synthesis in the body according to $\mathrm{Wu},(2010)$, and Darling et al.(1999), it has been reported that the amount of glycine synthesized in vivo is insufficient to meet metabolic demands in these species according to Jackson (1991), Melendez-Heviaet al. (2009), and Rezaeiet al., (2013).

Other functions of glycine include: protection of the body against hyper toxicity by effectively and successively fighting against ethanol induced toxicity according to Senthilkumar et al (2004), Zeb and Rahman (2017), an effective therapy for shocks, Abello et al (1994), treatment of gastric ulcer by decreasing the acid secretions caused by pylorus ligation, prevention of organ transplanting failure (kidneys) when treated with a solution containing glycine and Carolina, Zeb and Rahman (2017). This mixture helps to protect the kidneys against storage injury as well as long survival after kidney transplantation Yin et al (2002). Glycine is a very successful immunomodulatory that suppresses inflammation. It also prevents aging in human system. Glycine could also help in the correction of erectile dysfunction, enables proper circulation of blood, helps in cholesterol reduction, prevention of diabetes, hair loss, insomnia and menopause, boosting of the immune system, quickens surgery recovery, improves fertility, it also helps 
in weight loss and well-being. Shortage of glycine in small quantities is not harmful for health but severe shortage may lead to failure of immune response, low growth, abnormal nutrient metabolism as well as other undesirable effects on health, Lewis et al (2005). A typical example of a glycine derivative that can bring about reduction of cholesterol level in the body is dimethylglycine 21.<smiles>CN(C)CC(=O)O</smiles>

\section{Dimethyl glycine 21}

Figure 2: Structure of dimethylglycine

Esters are products obtained from the reaction of carboxylic acids and alcohols with the elimination of a water molecule by the process of esterification as shown in the reaction scheme below IUPAC, "in the Gold Book (1997).

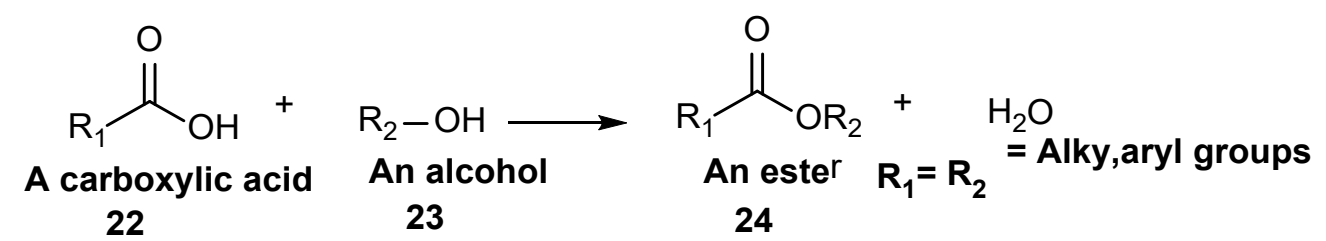

Figure 3: Reaction scheme for esters synthesis

Amides 26 on the other hand are compounds derived from the reaction of a carboxylic acid and an amino compound where a carboxylic acid group, and in an amide is replaced by the $-\mathrm{NH}$ of an $\mathrm{NH}_{2}$ group as shown below, Montalbetti and Falque (2005), Smith and March (2007).

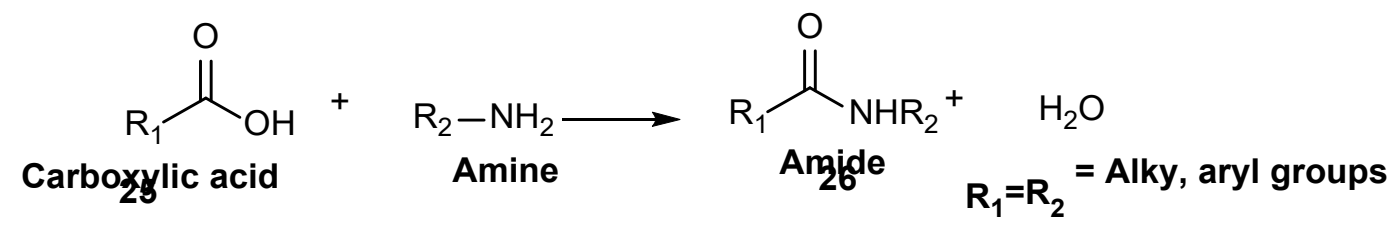

Figure 4: Reaction scheme for amides synthesis

Amide derivatives have been reported to possess broad spectrum of biological activities such as antituberculosis, Mohamed et al (2007), anticonvulsant, Nadeemet al (2008), analgesic, anti-inflammatory, Galewicz-Walesa et al (2003), insecticidal, Graybillet al (1992), antifungal, Mihealaet al (2008), and antitumor properties, Andre et al (2007). Compounds containing amide functionalities have proven to be potentially active against various fungal strains and many of them have got wide acceptance in clinical trials according to Ledmicer and Mitschen (1980); Delegado and Remars (2004). They are considered as pro-drugs, biologically inactive compounds which can be metabolized in the body to produce drug activity, Surrender et al (2010).

Cyclooxygenase (COX) officially known as prostaglandin-endoperoxide synthase (PTGS) is an enzymethat is responsiblefor formation of prostanoids, including thromboxane and prostaglandins such as prostacyclin, from arachidonic acid, Kristina et al (2006). Various prostaglandin synthases then convert $\mathrm{PGH}_{2}$ into several different prostaglandins and thromboxanes, Liu et al (2006). These prostaglandins and thromboxanes target specific G protein-coupled receptors and play major roles in regulation of renal function, platelet aggregation, protection of the stomach lining, and other numerous biological tasks, as well as mediation of the cellular inflammatory response, Kristina et al (2006) and Liu et al (2006). These functions are attributed mainly to the first of the two established COX isoforms, the COX-1, while the inflammatory response is largely associated with the inducible isoform, COX-2. Pharmaceutical inhibition of COX can provide relief from the symptoms of inflammation and pain. Those that are specific to the COX-2 isozyme are called COX-2 inhibitors. For example the active metabolite (AM404) of paracetamol believed to provide most or all of its analgesic effects is a COX inhibitor, and this is believed to provide part of its 
effect, Liu et al (2006) and Högestätt et al (2005). Inhibition of COX-2 produces the analgesic, antipyretic, and antiinflammatory effects typical of non-steroidal anti-inflammatory drugs (NSAIDs), while inhibition of COX-1 is responsible for the antithrombotic effects of aspirin and other nonselective NSAIDs, as well as many of their side effects, such as gastric ulcer formation. The many therapeutically useful effects of COX inhibition have made the NSAIDs among the most widely used drugs of the past century according to Högestätt et al (2005). Since selective COX-2 inhibition can provide analgesic and anti-inflammatory effects with reduced undesirable gastric side effects, COX-2 selective inhibitors such as celecoxib and rofecoxib have become some of the most widely used prescription medications in the developed world. However, recent reports that COX-2 selective inhibitors may increase the risk of heart attack in some patients has caused great concern, and stimulated increased interest in these enzymes, Masferrer et al (1994) and Solomon et al (2002).
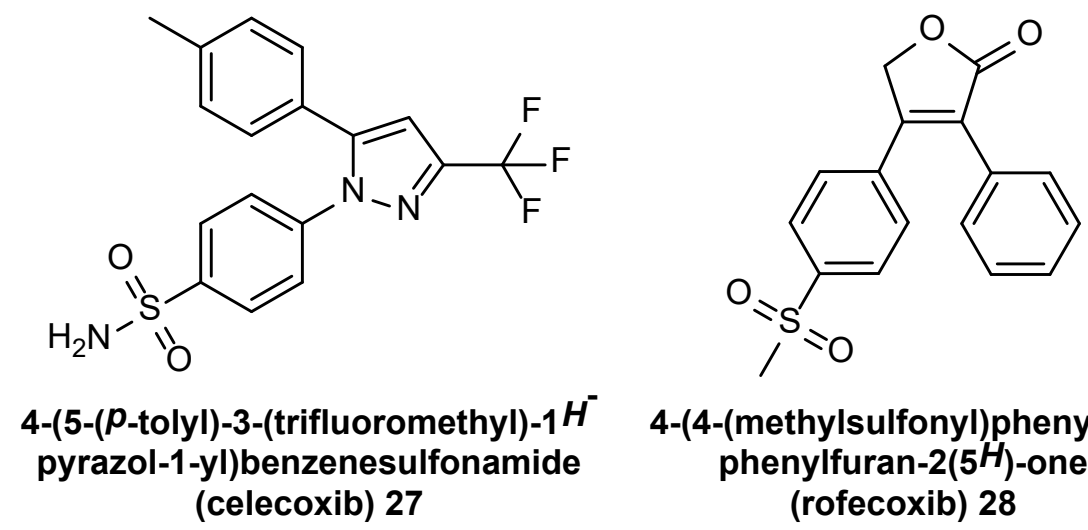

\section{4-(4-(methylsulfonyl)phenyl)-3- \\ phenylfuran-2(5H)-one \\ (rofecoxib) 28}

Figure 5: Structures of Celecoxib and Rofecoxib

In this paper we have reported the successful synthesis as well the determination of the binding energies of novel ethyl-glycinate amide derivatives with the COX-2 construct which was used to obtain the 1CVU crystal structure for molecular docking in order compare their binding energy with the standard drugs, celecoxib and rofecoxib respectively used as COX-2 inhibitors. This is to determine if these derivatives could also serve as good drug molecules that can inhibit COX-2 enzyme or not.

\section{EXPERIMENTAL}

All the reagents were purchased from commercial supplier, Aldrich, and were used without further purification. Melting points were determined with electro thermal melting points apparatus in open capillaries and are uncorrected. UV and Visible spectra were recorded in DMF on a Jenway $6405 \mathrm{UV} / \mathrm{Vis}$ spectrophotometer, using matched $1 \mathrm{~cm}$ quartz cell. IR spectra in (KBr) on a FTIR (NARICT, Zaria), ${ }^{1} \mathrm{H}-\mathrm{NMR}$ and ${ }^{13} \mathrm{C}-\mathrm{NMR}$ on a JEOL Associate E-400 instrument (chemical shift are reported on the $\delta$ scale relative to tetramelthylsilane (TMS) as an internal standard) and mass spectra on a Shimadzu QP2010 spectrophotometer. Analytical samples were obtained by column chromatography on aluminum oxide 90 (Merck, 70-230 Mesh ASTM) employing ethano-chloroform (9:1) as eluting solvent before recrystallization. The 3.0 Å resolution X-ray crystal structure of the ovine COX-1/AA complex, pdb entry $1 \mathrm{CVU}$, was used to generate the initial model.

\subsection{ETHYL GLYCINATE 29}

The compound glycine ethyl ester $\mathbf{9 8}$ was prepared by using the esterification reaction of glycine $\mathbf{1}$ with ethanol in the presence of hydrochloric acid as a catalyst, Jiabo and Yaowu (2008) and Fischer and Speier (1895). A mixture of glycine $(15.0 \mathrm{~g}, 0.15 \mathrm{~mol})$, ethanol $(200 \mathrm{ml})$ and conc. hydrochloric acid $(7 \mathrm{ml})$ was refluxed for $15 \mathrm{~h}$, at $78^{\circ} \mathrm{C}$. At the end of the reaction, the mixture was placed in a water bath and evaporated. The evaporated product was kept in an airtight desiccator for a week and a crystalline whitish product was obtained. This was later recrystallized from ethanol mixed with a little quantity of diethyl ether to precipitate the final product $(14.50 \mathrm{~g}, 96.5 \%)$. This was further dried for some days and brilliant white crystals were obtained, melting at $188.2^{\circ} \mathrm{C}$.The UV-Vis: $\lambda \max , 334 \mathrm{~nm}(\varepsilon=$ 8.4). IR (KBr): $3119 \mathrm{~cm}^{-1}$ (N-H stretching), $2838 \mathrm{~cm}^{-1}$ (C-H stretching), $1718 \mathrm{~cm}^{-1}$ (C=O stretching), $1490 \mathrm{~cm}^{-1}(\mathrm{C}-\mathrm{N}$ 
Eugene L. Ayuk, Precious A. Afoke, Samuel B. Aronimo, and Temitayo A. Olowolafe

stretching), $1244 \mathrm{~cm}^{-1}$ (C-O stretching). ${ }^{1} \mathrm{H}-\mathrm{NMR}\left(\mathrm{DMSOd}_{6}\right) \delta \mathrm{ppm:} 8.70$ (singlet, $2 \mathrm{H}, 1^{\circ}$ amine), 4.16 (triplet, $2 \mathrm{H}$, methylene protons), 4.04(singlet, $2 \mathrm{H}$, methylene protons), 1.2 (doublet, $3 \mathrm{H}$, methyl protons). ${ }^{13} \mathrm{C}-\mathrm{NMR}$ (DMSOd 6$)$ ppm: 167.6 (1C, carbonyl), 61.0 (1C, methylene), 41,8 (1C, methylene), 14.6 (1C, methyl).

\subsection{2-AMINO-N- (4-NITROPHENYL) ACETAMIDE (31)}

The compound, 2-amino- $N$-(4-nitrophenyl) acetamide $\mathbf{3 1}$ was prepared by the reaction of the synthesized glycine ethyl ester $29(2.0 \mathrm{~g}, 0.02 \mathrm{~mol})$ and 4 -nitroaniline $30(2.0 \mathrm{~g}, 0.01 \mathrm{~mol})$ with the stoichiometric ratio of $2: 2$. Both compounds were dissolved in $(50 \mathrm{ml})$ ethanol and boiled under reflux for $4 \mathrm{~h}$. The crude product was obtained with the help of a rotary evaporator under reduced pressure. This was dried and subjected to column chromatography using a mixture of ethanol and chloroform (9:1) as eluting solvent followed by recrystallization, to give a brownyellowish compound 31, yield 3.76g (94.0\%), melting point, $186.2^{\circ} \mathrm{C}$. UV-Vis $-\lambda_{\max }(\varepsilon) 344 \mathrm{~nm}(18.0) 364 \mathrm{~nm}(19.5)$ 425nm (22.2) 445nm (21.6) 465nm (21.3).IR (KBr): 3481 cm-1 (N-H stretching), $2838 \mathrm{~cm}^{-1}$ (C-H stretching), $1751 \mathrm{~cm}-$ ${ }^{1}\left(\mathrm{C}=0\right.$ stretching) $1625 \mathrm{~cm}^{-1}(\mathrm{C}=\mathrm{C}$ stretching $), 1584 \mathrm{~cm}^{-1}(\mathrm{C}-\mathrm{N}$ stretching $), 913 \mathrm{~cm}^{-1}(\mathrm{C}-\mathrm{H}$ bending out of plane of aromatic ring). ${ }^{1} \mathrm{H}-\mathrm{NMR}\left(\mathrm{DMSOd}_{6}\right) \delta \mathrm{ppm}: 10.23$ (singlet, $1 \mathrm{H}$, amide proton), 8.70 (triplet, $2 \mathrm{H}, 1^{\circ}$ amine protons), 8.17 (doublet, $2 \mathrm{H}$, aromatic protons), 7.82 (doublet, $2 \mathrm{H}$, aromatic protons), 3.85 (triplets $2 \mathrm{H}$, methylene protons). ${ }^{13} \mathrm{C}$ NMR (DMSOd $\left.{ }_{6}\right) \delta$ ppm: 168.5 (1C, carbonyl), 144.6 (1C, Aromatic-C-NO 2 ), 143.5 (1C, Aromatic-C-N), 124.1 (2C, aromatic), 119.9 (2C, aromatic), 43.2 (1C, methylene).

\subsection{2-AMINO-N-(6-METHYLPYRIDIN-2-YL) ACETAMIDE 33}

The compound 2-Amino- $N$-(6-methylpyridyl) acetamide 33 was prepared by the reaction of ethyl glycinate 29 $(2.0 \mathrm{~g}, 0.02 \mathrm{~mol})$ and 2-amino-6-methylpyridine $32(2.0 \mathrm{~g}, 0.02 \mathrm{~mol})$ in the ratio of 2:2 respectively. These compounds were dissolved in 50 mlethanol and boiled under reflux for $4 \mathrm{~h}$. The crude product was obtained with the help of a rotary evaporator under reduced pressure. This was dried and subjected to column chromatography using a mixture of ethanol and chloroform (9:1) as eluting solvent followed by recrystallization, to give a whitish crystalline compound 33, yield 3.56g (89.0\%), melting at 202.1 ${ }^{\circ} \mathrm{C}$. UV-Vis $-\lambda_{\max }(\varepsilon)$; $354 \mathrm{~nm}(15.09)$; IR (KBr): $3090 \mathrm{~cm}^{-1}(\mathrm{~N}-\mathrm{H}$ stretching), $2806 \mathrm{~cm}^{-1}$ (C-H stretching), $1662 \mathrm{~cm}^{-1}\left(\mathrm{C}=0\right.$ stretching), $1572 \mathrm{~cm}^{-1}\left(\mathrm{C}=\mathrm{N}\right.$ stretching), $924 \mathrm{~cm}^{-1}$ (C-Hbending of aromatics). ${ }^{1} \mathrm{H}-\mathrm{NMR}$ (DMSOd 6 ) $\delta$ ppm: 11.14 (singlet, $1 \mathrm{H}$, amide proton), 8.70 (triplet, $2 \mathrm{H}, 1^{\circ}$ amine protons), 8.17 (doublet, $2 \mathrm{H}$, aromatic protons), 7.96 (singlet, $1 \mathrm{H}$, aromatic proton),7.89 (singlet, $1 \mathrm{H}$, aromatic proton), 6.88 (singlet, $1 \mathrm{H}$, aromatic proton), 3.85 (triplets $2 \mathrm{H}$, methylene protons); ${ }^{13} \mathrm{C}-\mathrm{NMR}$ (DMSOd 6 ) $\delta$ ppm: $168.5(1 \mathrm{C}$, carbonyl), 151.5 (2C, aromatic-C-N), 149.5 (1C, aromatic-C-N), 143.5 (1C, C-NO ${ }_{2}$ ), 125.5 (1C, aromatic), 112.8 (2C, aromatic), 43.2 (1C, methylene), 23.9 (1C, methyl).

\section{4. $N, N^{\prime}$-(1,4-PHENYLENE)-BIS-(2-AMINOACETAMIDE) 35}

The compound 1,4-(2,2-diamino- $N, N^{\prime}$-phenyl) diacetamide 35 was prepared by the reaction of glycine ester 29 $(2.0 \mathrm{~g}, 0.02 \mathrm{~mol})$ and 1,4 -diamino- $N, N^{\prime}$-benzene $34(1.0 \mathrm{~g}, 0.01 \mathrm{~mol})$ with the ratio of 2:1 respectively. Both compounds were dissolved in $50 \mathrm{ml}$ ethanol and left to boil under reflux for $4 \mathrm{~h}$, thereafter the crude product was obtained with the help of a rotary evaporator under reduced pressure. This was dried and subjected to column chromatography using a mixture of ethanol and chloroform (9:1) as eluting solvent followed by recrystallization, to give a black compound 35, yield $2.84 \mathrm{~g}(94.7 \%)$, melting at $235.4^{\circ} \mathrm{C}$. UV-Vis $-\lambda_{\max }(\varepsilon) ; 354 \mathrm{~nm}(20.3) 420 \mathrm{~nm}(24.8) 547 \mathrm{~nm}(28.7)$ 597nm (29.6); IR (KBr): $3451 \mathrm{~cm}^{-1}$ (N-H stretching), $2944 \mathrm{~cm}^{-1}$ (C-H stretching), $1668 \mathrm{~cm}-1$ (C=0 stretching), $1386 \mathrm{~cm}^{-}$ ${ }^{1}$ (C-N stretching), 682 $\mathrm{cm}^{-1}$ (C-H bending of aromatics). ${ }^{1} \mathrm{H}-\mathrm{NMR}$ (DMSOd ${ }_{6}$ ) $\delta \mathrm{ppm}: 10.23$ (singlet, $2 \mathrm{H}$, amide protons), 8.70 (triplet, $4 \mathrm{H}, 1^{\circ}$ amine protons), 7.57 (singlet, $4 \mathrm{H}$, aromatic protons), 3.85 (triplets $4 \mathrm{H}$, methylene protons); ${ }^{13} \mathrm{C}-$ NMR (DMSOd ${ }_{6} \delta$ ppm: 168.5 (2Cs, carbonyl), 134.1 (2C, aromatic-C-N), 121.8 (4C, aromatic-C-N), 43.2 (1C, methylene).

\section{5. $N$, $N^{\prime}$-(6-CHLOROPYRIMIDINE-2,4-DIYL)-BIS-(2-AMINOACETAMIDE) 37}

The compound 2,6-(2,2-diamino- $N$, $N^{\prime}$-4-chloropyrimidyl) diacetamide 37 was prepared by the reaction of ethyl glycinante $29(2.0 \mathrm{~g}, 0.02 \mathrm{~mol})$ and 2,6-diamino-4-chloro-pyrimidine $36(1.0 \mathrm{~g}, 0.01 \mathrm{~mol})$ with the ratio of $2: 1$. Both 
Synthesis and Preliminary Molecular Docking Studies of Novel Ethyl-glycinate Amide Derivatives

compounds were dissolved in $50 \mathrm{ml}$ ethanol and left to boil under reflux for $4 \mathrm{~h}$, thereafter the crude product was obtained with the help of a rotary evaporator under reduced pressure. This was dried and subjected to column chromatography using a mixture of ethanol and chloroform $(9: 1)$ as eluting solvent followed by recrystallization, to give a whitish compound 37 , yield $1.48 \mathrm{~g}(49.6 \%)$, melting at $168.6^{\circ} \mathrm{C}$. UV-Vis $-\lambda_{\max }(\varepsilon)$; $344 \mathrm{~nm}(3.6)$. IR (KBr): $3451 \mathrm{~cm}^{-1}\left(\mathrm{~N}-\mathrm{H}\right.$ stretching), $3011 \mathrm{~cm}^{-1}$ (C-H stretching), $1684 \mathrm{~cm}^{-1}\left(\mathrm{C}=0\right.$ stretching) $1628 \mathrm{~cm}^{-1} \mathrm{C}=\mathrm{N}$ stretching, $874 \mathrm{~cm}^{-1}$ (C-H bending of aromatics). ${ }^{1} \mathrm{H}-\mathrm{NMR}\left(\mathrm{DMSOd}_{6}\right) \delta \mathrm{ppm}$ : 11.14 (singlet, $1 \mathrm{H}$, amide protons), 10.30 (singlet, $1 \mathrm{H}$, amide protons) 8.70 (triplet, $4 \mathrm{H}, 1^{\circ}$ amine protons), 8.14 (singlet, $4 \mathrm{H}$, aromatic protons), 3.80 (singlet $4 \mathrm{H}$, methylene protons); ${ }^{13} \mathrm{C}-\mathrm{NMR}$ (DMSOd 6 ) $\delta$ ppm: 168.5 (2Cs, carbonyl), 161.4 (1C, aromatic-Cl), 147.6 (1C, aromatic-C-N), 105.5 (2C, aromatic), 43.2 (2C, methylene).

\subsection{2-AMINO-N-(4-HYDROXY-6-UREIDOPYRIMIDIN-2-YL) ACETAMIDE 39}

The compound 2,4-(diamino- $N, N^{\prime}$-6-hydroxypyrimidyl) diacetamide 39 was prepared from the reaction of ethyl glycinate $29(2.0 \mathrm{~g}, 0.02 \mathrm{~mol})$ and 2,4-diamino-6-hydroxypyrimidine $38(1.0 \mathrm{~g}, 0.01 \mathrm{~mol})$ with the ratio of 2:1. Both compounds were dissolved in $50 \mathrm{ml}$ ethanol and left to boil under reflux for $4 \mathrm{~h}$, thereafter the crude product was obtained with the help of a rotary evaporator under reduced pressure. This was dried and subjected to column chromatography using a mixture of ethanol and chloroform (9:1) as eluting solvent followed by recrystallization, to give a whitish crystalline compound 39, yield $2.77 \mathrm{~g}(94.7 \%)$, melting at $227.3^{\circ} \mathrm{C} . \mathrm{UV}-\mathrm{Vis}-\lambda_{\max }(\varepsilon) ; 359 \mathrm{~nm}(19.9)$; IR(KBr): $3324 \mathrm{~cm}^{-1} \quad \mathrm{O}-\mathrm{H}$ stretching, $3281 \mathrm{~cm}^{-1}$ (N-H stretching), $2993 \mathrm{~cm}^{-1}\left(\mathrm{C}-\mathrm{H}\right.$ stretching), $1673 \mathrm{~cm}^{-1}(\mathrm{C}=0$ stretching), $1506 \mathrm{~cm}^{-1}$ ( $\mathrm{C}=\mathrm{N}$ stretching) $1133 \mathrm{~cm}^{-1}\left(\mathrm{C}-\mathrm{O}\right.$ stretching), $883 \mathrm{~cm}^{-1}$ (C-H bending). ${ }^{1} \mathrm{H}-\mathrm{NMR}\left(\mathrm{DMSOd}_{6}\right) \delta \mathrm{ppm:}$ 11.62 (s, 1H, OH), 11.14 (singlet, $1 \mathrm{H}$, amide protons), 10.30 (singlet, $1 \mathrm{H}$, amide protons) 8.70 (triplet, $4 \mathrm{H}, 1^{\circ} \mathrm{amine}$ protons), 7.37 (singlet, $4 \mathrm{H}$, aromatic protons), 3.80 (singlet $4 \mathrm{H}$, methylene protons); ${ }^{13} \mathrm{C}-\mathrm{NMR}\left(\mathrm{DMSOd}_{6}\right) \delta \mathrm{ppm:}$ 168.5 (2Cs, carbonyl), 167.5 (1C, aromatic-OH), 151.3 (1C, aromatic-C-N), 138.8 (1C, aromatic-C-N), (101.3 (1C, aromatic), 43.2 (2C, methylene).

\subsection{MOLECULAR DOCKING EXPERIMENTS}

\subsubsection{PREPARATION OF LIGANDS}

The docking studies were carried out on a Zinox Laptop, Model T5101. ACD/ Chemdraw 2015 (Ref: ACD/Structure Elucidator, version 15.01, Advanced Chemistry Development, Inc., Toronto, ON, Canada, www.acdlabs.com, 2015.) was used to draw the structures of compounds 31-39 (Figs. $6,7,10,13,16,19$ and 22) and also convert them to 3D formats.

\subsubsection{PREPARATION OF PROTEIN TARGETS}

The 3D structure of the cyclooxygenase active site of COX-2(PDB: 1CVU) was retrieved from the RCSB Protein Data Bank (PDB) (www.rcsb.org/pdb/home/home.do), Picot et al (1994). All bound ligands, cofactors, andwater molecules were removed from the proteins using Discovery Studio Visualizer v16. 1.0. 15,350. All file conversions required for the docking study were performed using the open source chemical toolbox. Open Babel version 2.3.2 (www.openbabel.org). Finally Auto Dock was used to calculate the binding free energy of a given inhibitor conformation in the macromolecular structure.

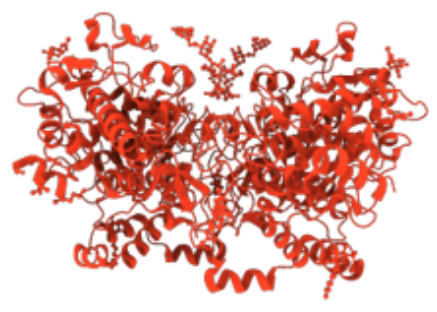

Figure 6: Structure of Cyclooxygenase-2 (+-PDB: 1CVU) 


\section{RESULT AND DISCUSSIONS}

The synthesis of ethyl glycinate $\mathbf{2 9}$ was achieved through Fischer esterification protocol, Jiabo and Yaowu (2008) and Fischer and Speier (1895) whereas its amide derivatives; 2-amino- $N$-(nitrophenyl)acetamide 31, 2 amino- $N$-(6-methylpyridin-2-yl) acetamide $\quad 33, \quad N, N^{\prime}$-(1,4-phenylene)bis-(2-aminoacetamide) $\quad 35, \quad N, N^{\prime}-(6-$ chloropyrimidine-2,4-diyl)bis-(2-aminoacetamide) 37 , and 2,4-(diamino- $N, N^{\prime}$-6-hydroxypyrimidyl)acetamide 39 respectively were synthesized by coupling reactions of the following starting reagents namely; 4-nitroaniline, 2amino-6-methylpyridine, 1,4-diamino-N,N'-benzene, 2,6-diamino-4-chloropyrimidine and 2,4-diamino-6hydroxypyrimidine respectively with the key intermediate, ethyl glycinate 29, FitzGerald (200). These compounds were characterized on the basis of their melting points, UV-Visible, IR, ${ }^{1} \mathrm{HNMR}$ and ${ }^{13} \mathrm{CNMR}$ spectroscopic analyses. The results obtained from the spectra were consistent with the assigned structures of the compounds. The ${ }^{1} \mathrm{HNMR}$ and ${ }^{13} \mathrm{CNMR}$ spectra as well as the reaction schemes for the synthesis of the above compounds are outline in the Figs (6-22) below;

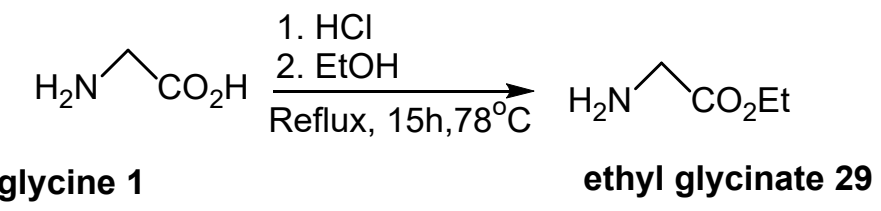

Figure 7: Reaction scheme for the synthesis of ethyl glycinate

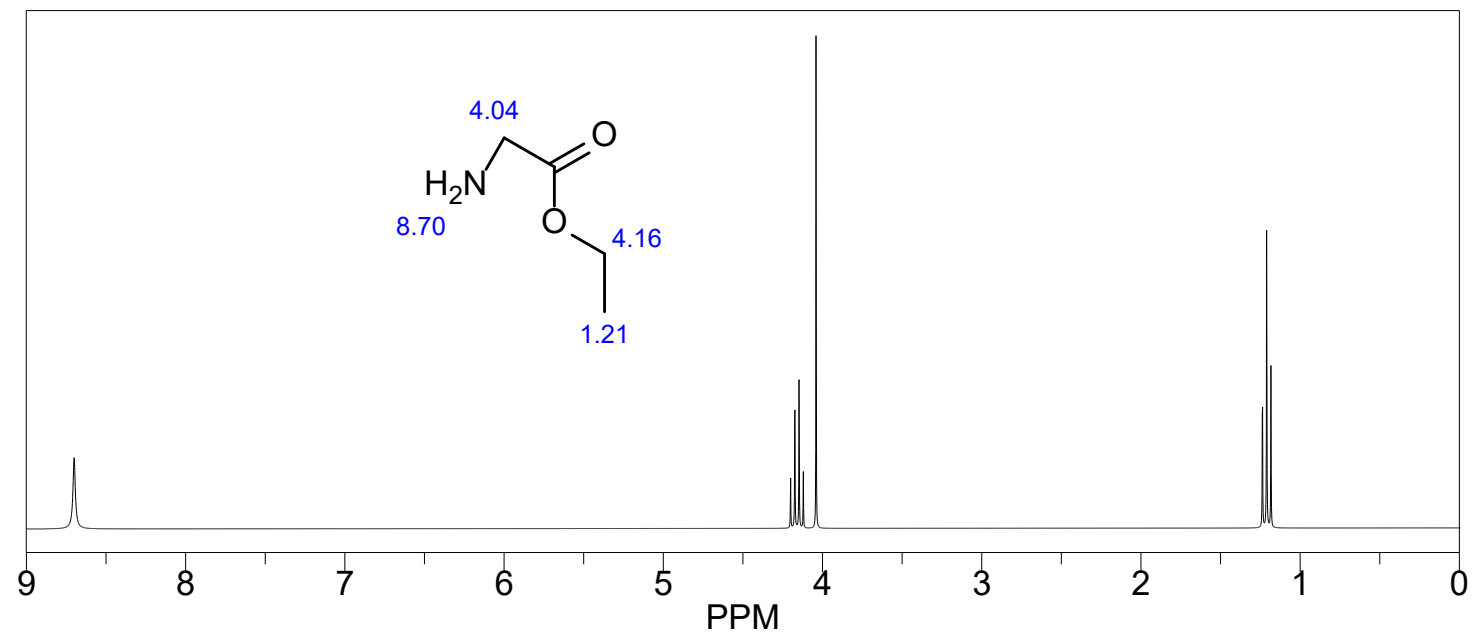

Figure 8: ${ }^{1} \mathrm{HNMR}$ spectrum of ethyl glycinate (29)

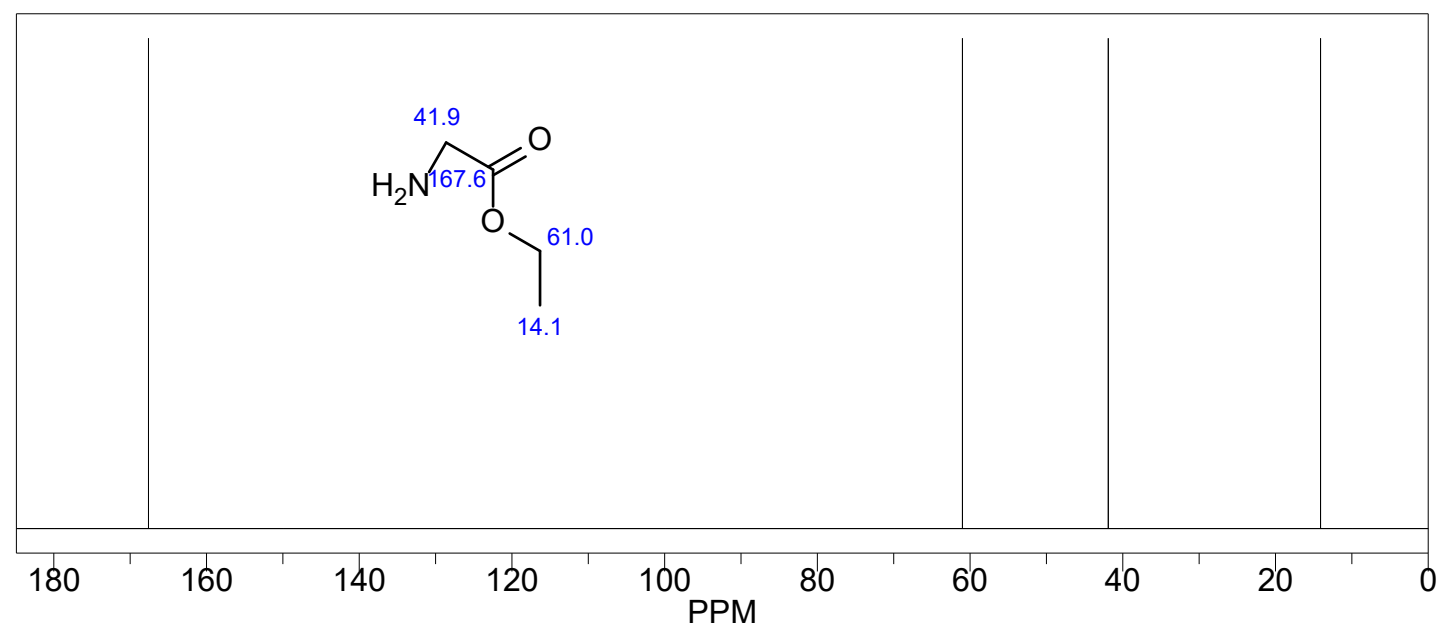

Figure 9: ${ }^{13} \mathrm{CNMR}$ spectrum of ethyl glycinate (29) 
Synthesis and Preliminary Molecular Docking Studies of Novel Ethyl-glycinate Amide Derivatives

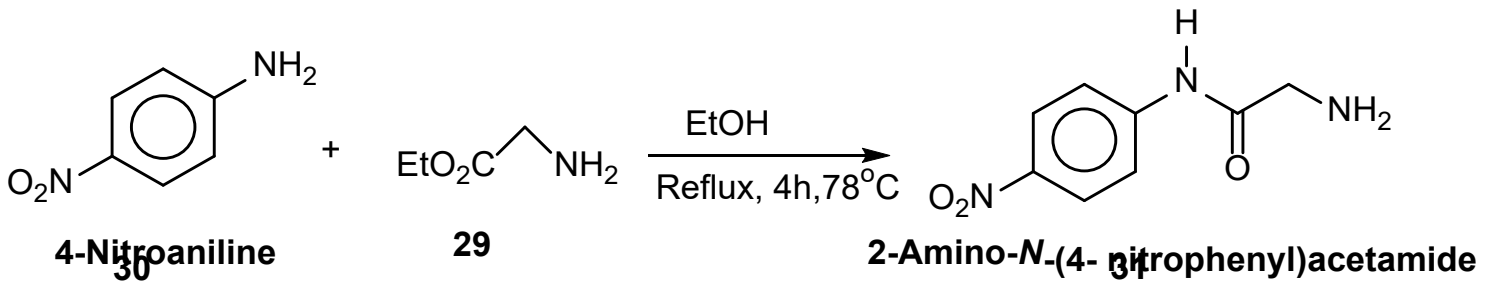

Figure 10: Reaction scheme for the synthesis of 2-amino- $N$-(4-nitrophenyl) acetamide (31)

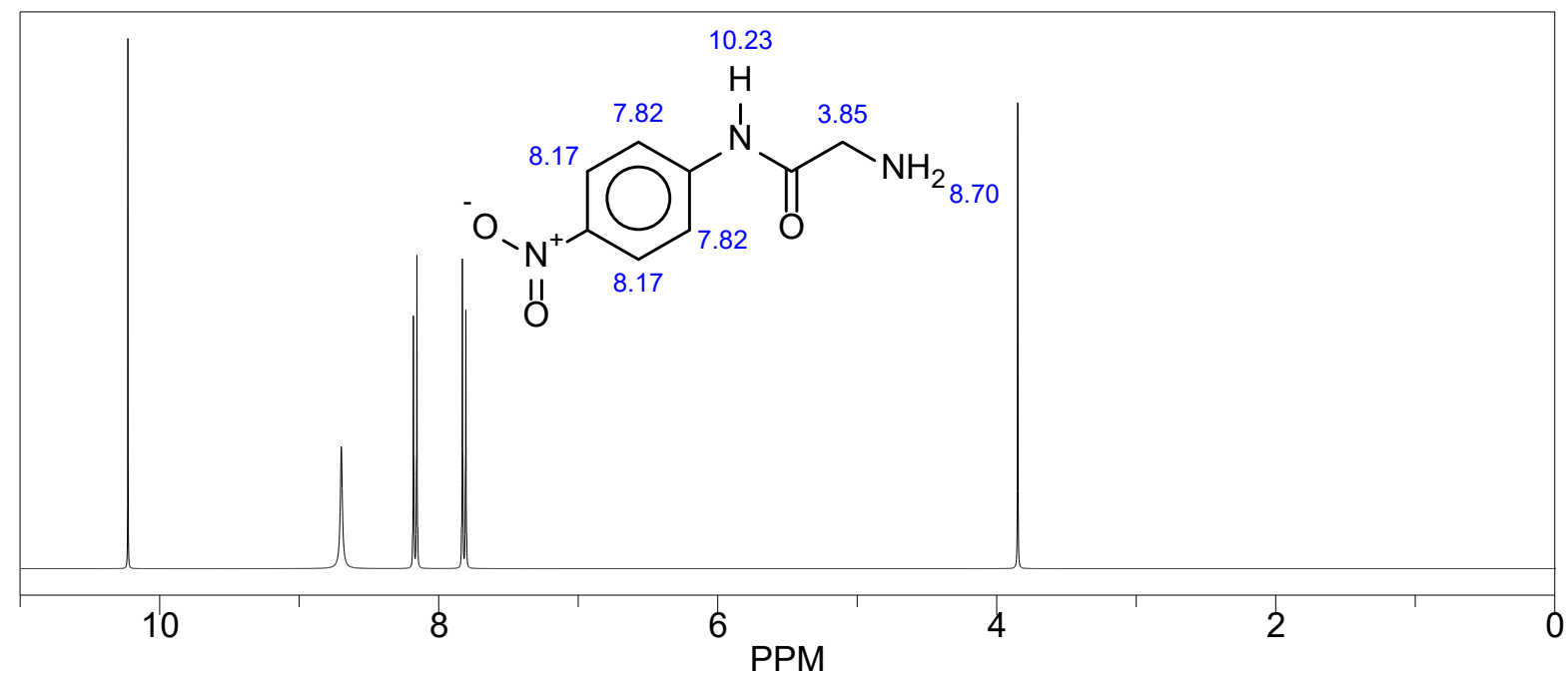

Figure 11: ${ }^{1} \mathrm{HNMR}$ spectrum of 2-amino- $N$ - (4-nitrophenyl) acetamide (31)

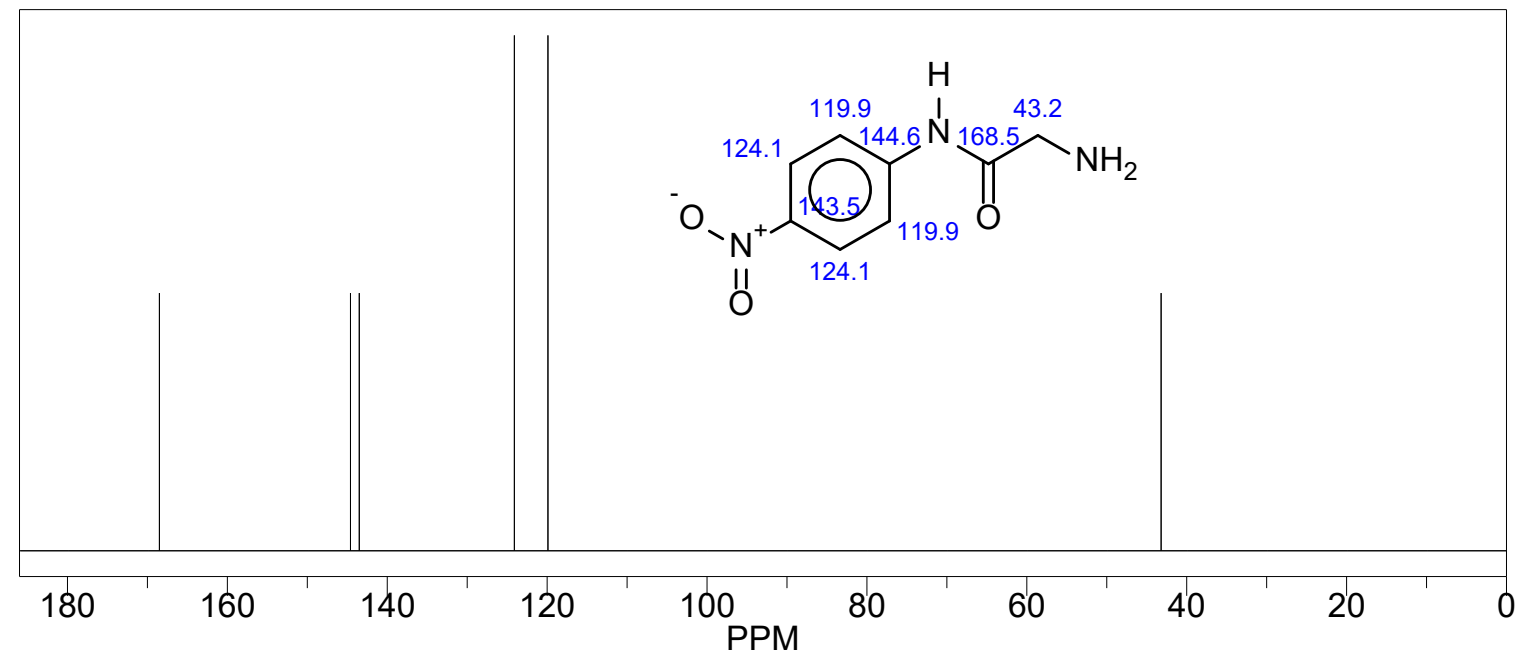

Figure 12:13CNMR spectrum of 2-amino- $N$ - (4-nitrophenyl) acetamide (31)

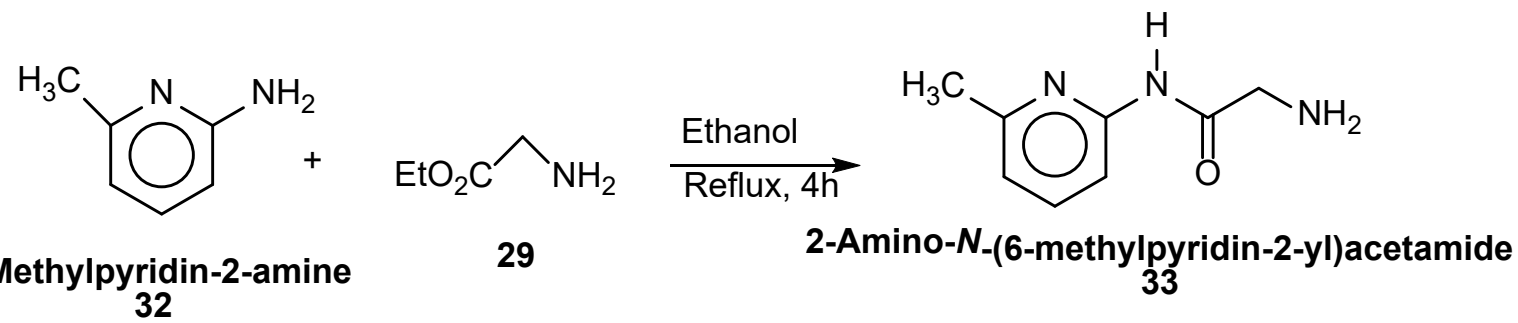

Figure 13: Reaction scheme for the synthesis of 2-Amino- $N$-(6-methylpyridin-2-yl) acetamide (33) 
Eugene L. Ayuk, Precious A. Afoke, Samuel B. Aronimo, and Temitayo A. Olowolafe

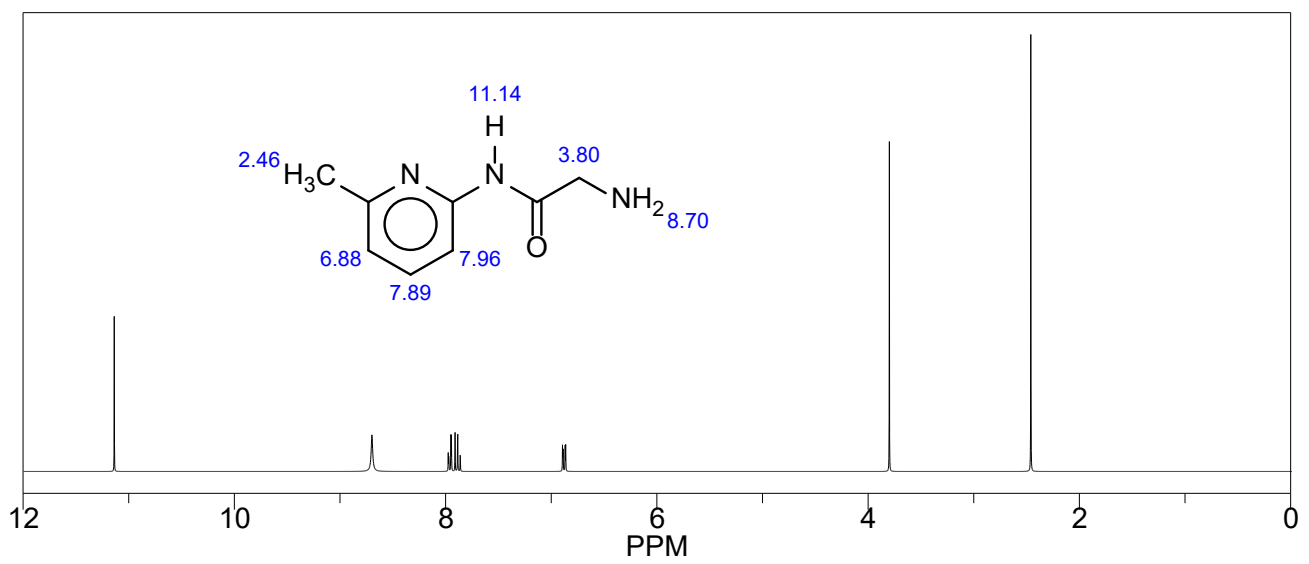

Figure 14: ${ }^{1} \mathrm{HNMR}$ spectrum of 2-Amino- $N$-(6-methylpyridin-2-yl) acetamide (33)

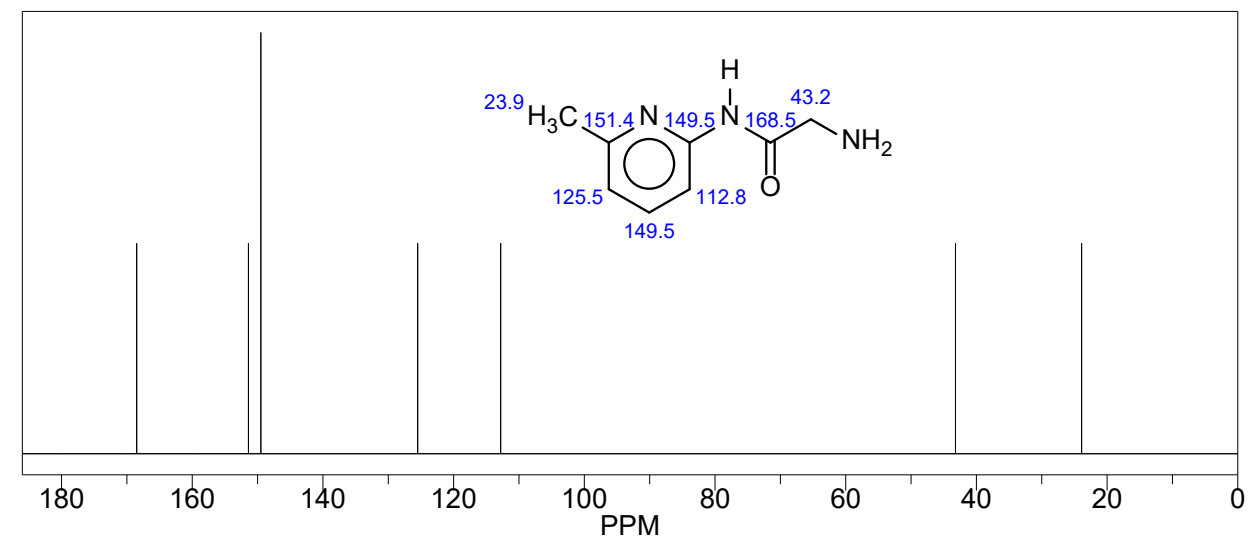

Figure 15: ${ }^{13} \mathrm{CNMR}$ spectrum of 2-Amino- $N$-(6-methylpyridin-2-yl) acetamide (33)

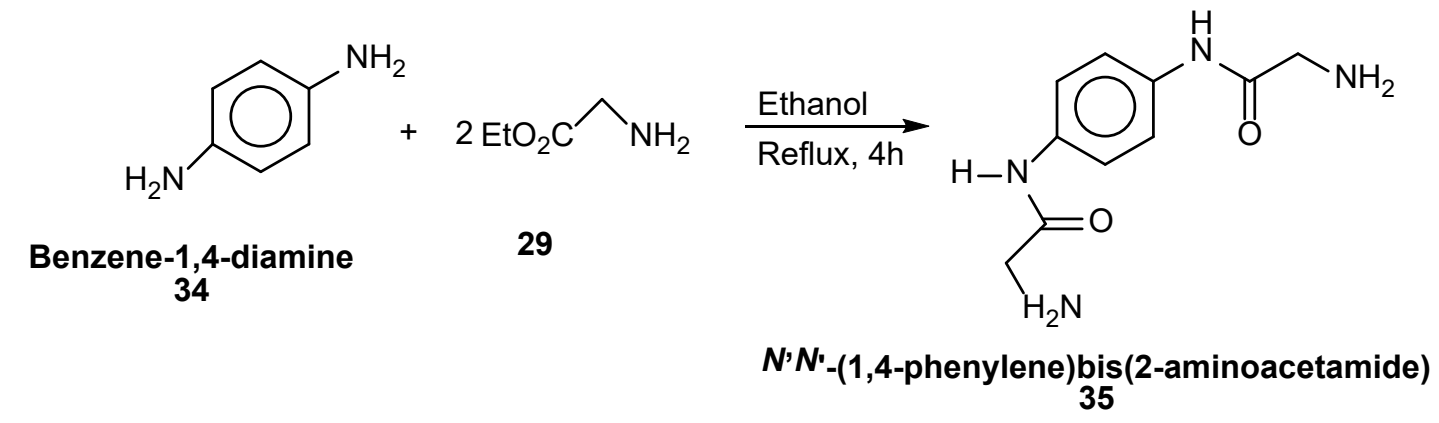

Figure 16: Reaction scheme for the synthesis of $N, N^{\prime}$-(1,4-phenylene)-bis-(2-aminoacetamide) (35)

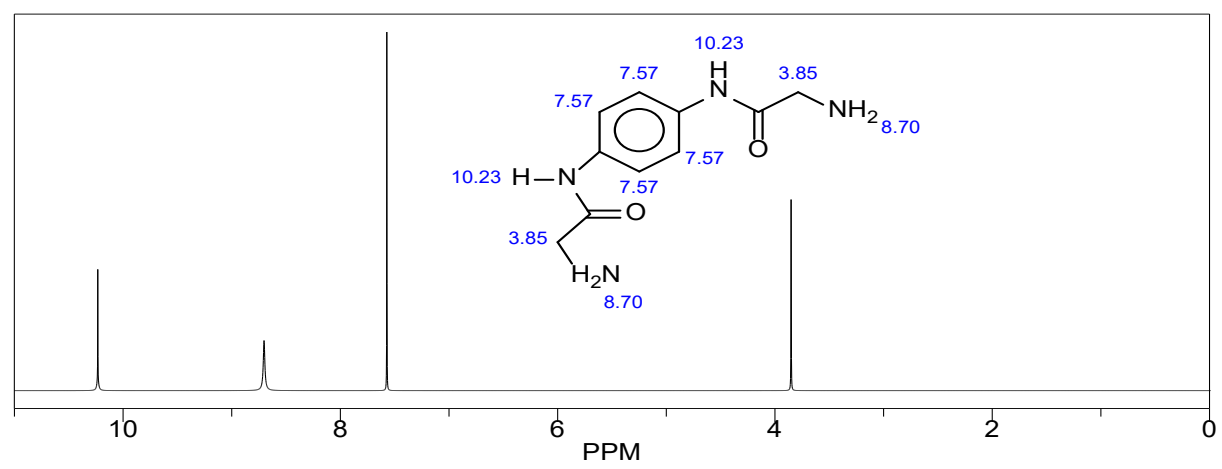

Figure 17: ${ }^{1} \mathrm{HNMR}$ spectrum of $N, N^{\prime}$-(1,4-phenylene)-bis-(2-aminoacetamide) (35) 
Synthesis and Preliminary Molecular Docking Studies of Novel Ethyl-glycinate Amide Derivatives

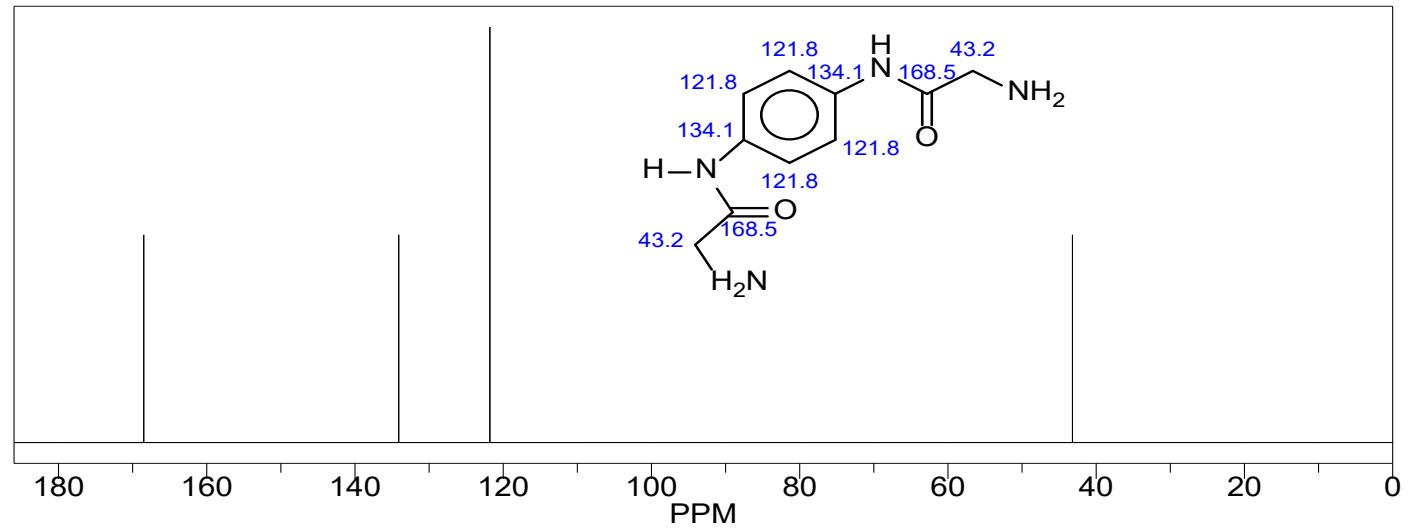

Figure 18: ${ }^{13} \mathrm{CNMR}$ spectrum of $N, N^{\prime}$-(1,4-phenylene)-bis-(2-aminoacetamide) (35)

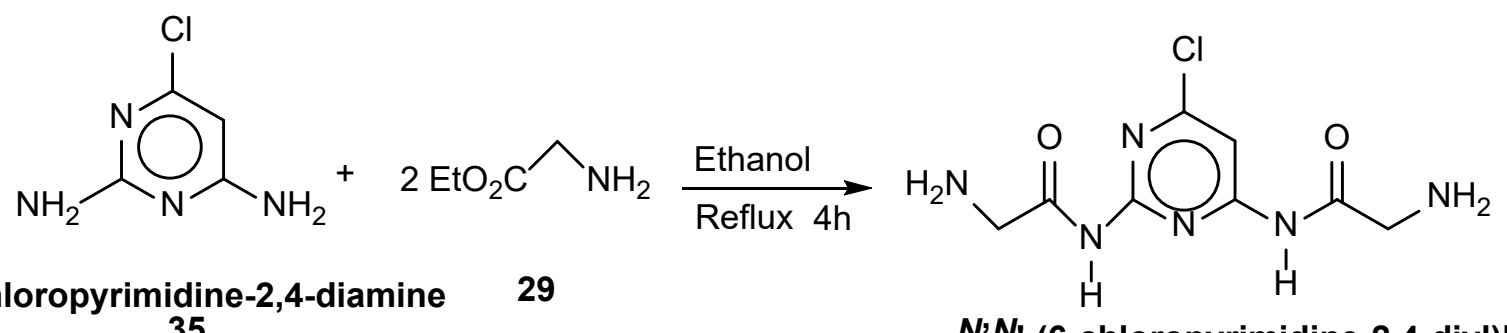

\section{6-Chloropyrimidine-2,4-diamine 29 35}

$N^{\prime} N^{\prime}-(6-c h l o r o p y r i m i d i n e-2,4-d i y l) b i s(2-$ aminoacetamide) 37

Figure 19: Reaction scheme for the synthesis of $N, N^{\prime}$-(6-Chloropyrimidine-2,4-diyl)-bis-(2-aminoacetamide) (37)

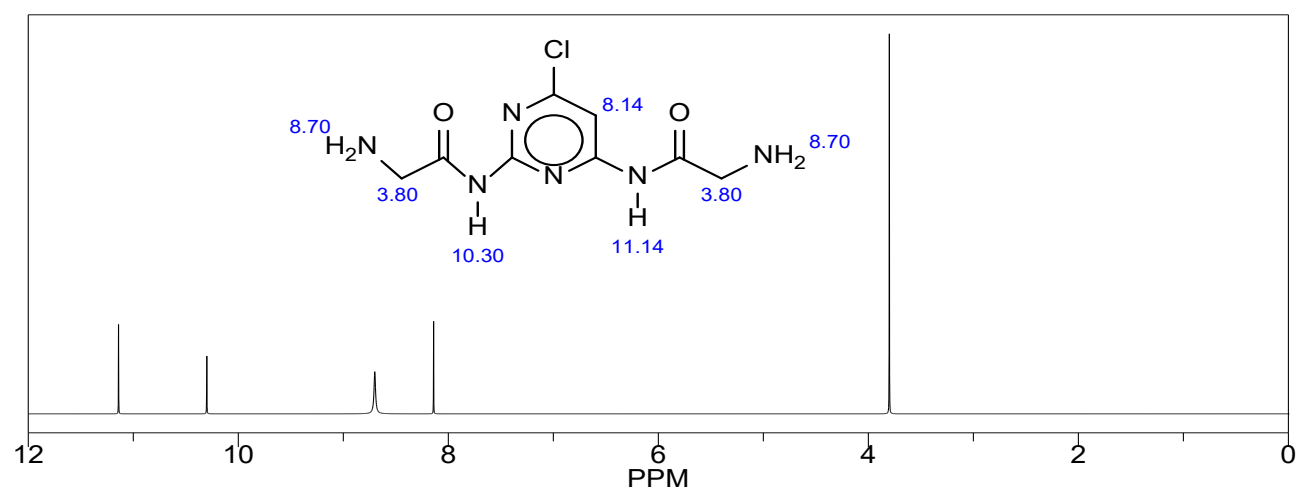

Figure 20: ${ }^{1} \mathrm{HNMR}$ of $N$, $N^{\prime}$-(6-Chloropyrimidine-2,4-diyl)-bis-(2-aminoacetamide) (37)

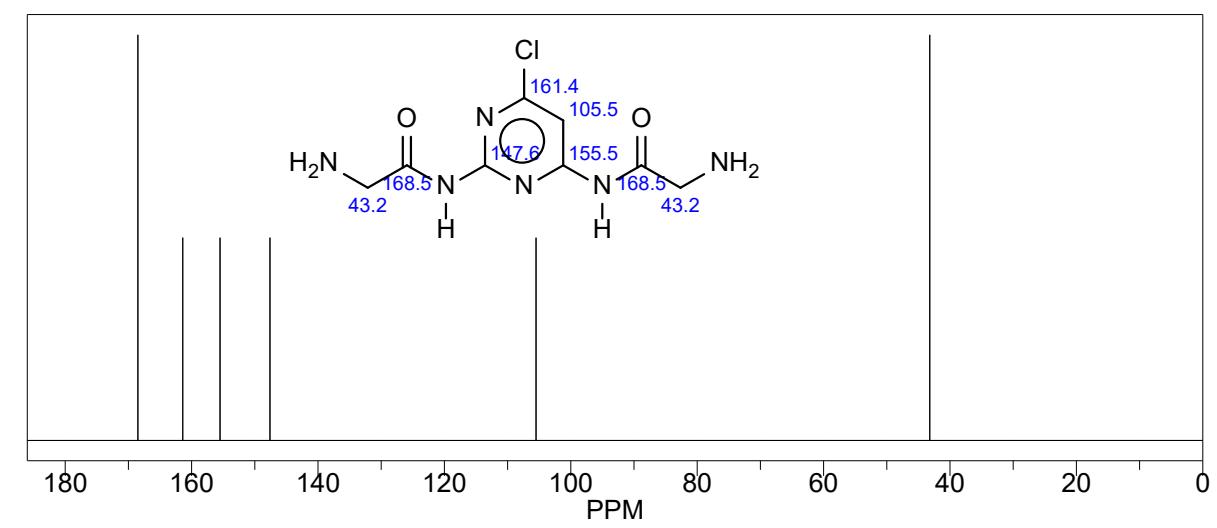

Figure 21: ${ }^{13} \mathrm{CNMR}$ of $N$, $N^{\prime}$-(6-Chloropyrimidine-2,4-diyl)-bis-(2-aminoacetamide) (37) 
Eugene L. Ayuk, Precious A. Afoke, Samuel B. Aronimo, and Temitayo A. Olowolafe<smiles>NCCOC(=O)CN</smiles><smiles>NCC(=O)Nc1cc(O)nc(NC(=O)CN)n1</smiles>

2,6-diaminopyrimidin-4-ol

29

2-Amino-N-(4-hydroxy-6-ureidopyrimidin-2-yl)acetamide 41

Figure 22: Reaction scheme for the synthesis of 2-amino- $N$-(4-hydroxy-6-ureidopyrimidin-2-yl)acetamide (39)

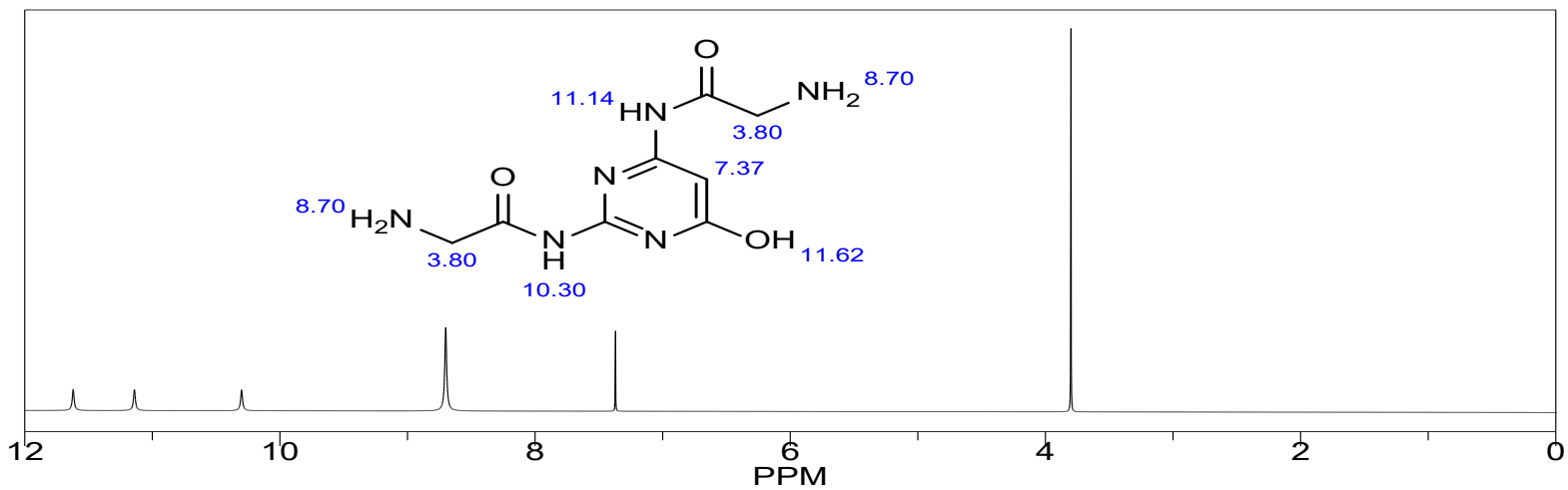

Figure 23: ${ }^{1} \mathrm{HNMR}$ of 2-amino- $N$-(4-hydroxy-6-ureidopyrimidin-2-yl) acetamide (39)

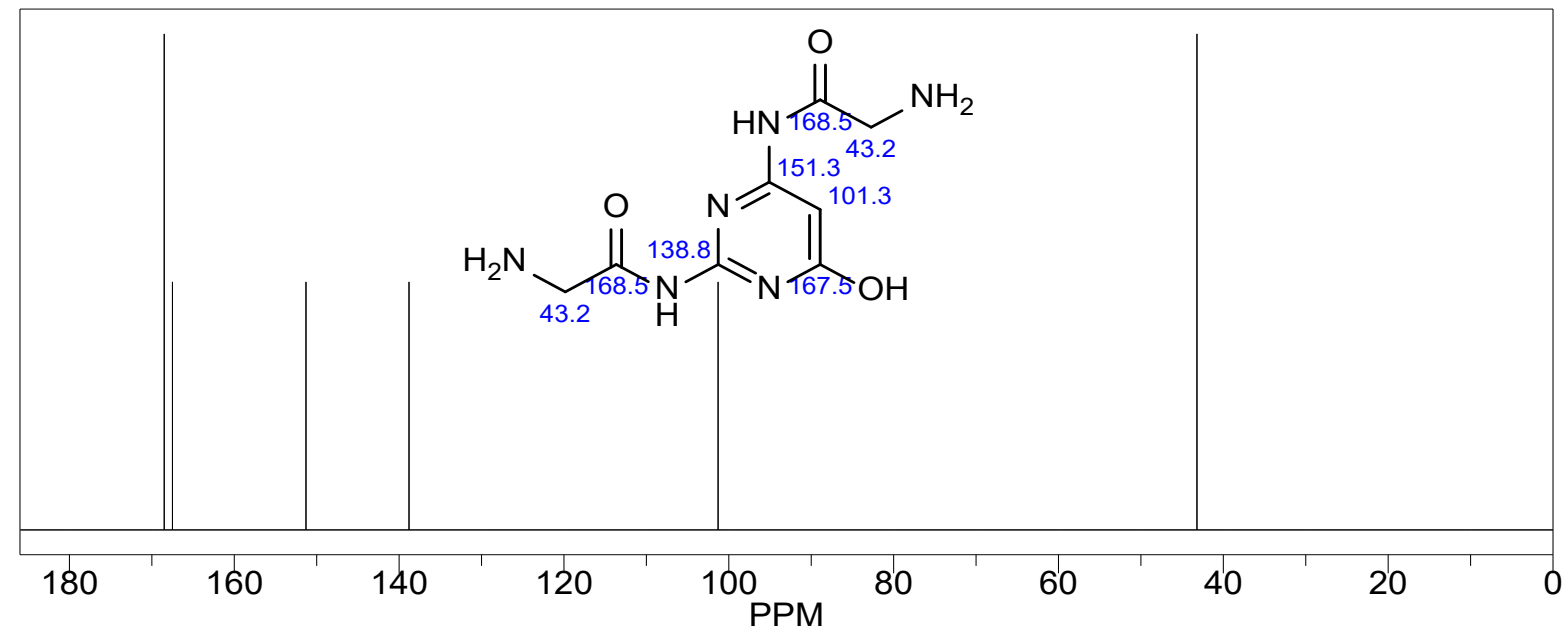

Figure 24: ${ }^{13} \mathrm{CNMR}$ of 2-amino- $N$-(4-hydroxy-6-ureidopyrimidin-2-yl) acetamide (39)

The synthesized compounds were subjected to molecular docking with a target protein, 1CVU to compare their binding energies with celecoxib and rofecoxib which are used as standard drugs for the inhibition of COX2 enzyme, Kurumbail (1994). From the docking result, the binding energy values of the above synthesized compounds were found to be $-5.8 \mathrm{kJmol}^{-1},-6.2 \mathrm{kJmol}^{-1},-7.2 \mathrm{kJmol}^{-1},-7.4 \mathrm{kJmol}^{-1}$ and $-7.6 \mathrm{kJmol}^{-1}$ respectively as shown in table 1 and the chart in Fig 23 below. These values are actually below that of the standard drugs; however compound (39) showed the highest binding energy of $-7.6 \mathrm{kJmol}^{-1}$, close to that for celecoxib and rofecoxib whose values are -8.0 $\mathrm{kJmol}^{-1}$ and $-8.2 \mathrm{kJmol}^{-1}$ respectively. This result indicates that compound (39) possess some level of inhibitory activity against COX2. 
Synthesis and Preliminary Molecular Docking Studies of Novel Ethyl-glycinate Amide Derivatives

Table 1: Binding energy $(\Delta G(\mathrm{~kJ} / \mathrm{mol})$ of the synthesized compounds with target protein, $1 \mathrm{CVU}$

\begin{tabular}{|c|c|c|}
\hline S/No & Compound & $\begin{array}{c}\text { Binding Affinity } \\
\Delta G(\mathrm{~kJ} / \mathrm{mol})\end{array}$ \\
\hline 1 & 2-Amino- $N$ - (4-nitrophenyl) acetamide31 & -5.8 \\
\hline 2 & 2 -Amino- $N$-(6-methylpyridin-2-yl) acetamide33 & -6.2 \\
\hline 3 & $N, N^{\prime}$-(1,4-Phenylene)-bis-(2-aminoacetamide)35 & -7.2 \\
\hline 4 & $N, N^{\prime}$-(6-Chloropyrimidine-2,4-diyl)-bis-(2-aminoacetamide)37 & -7.4 \\
\hline 5 & 2-Amino- $N$-(4-hydroxy-6-ureidopyrimidin-2-yl) acetamide39 & -7.6 \\
\hline & Celecoxib (standard COX2 Inhibitor) & -8.0 \\
\hline & Rofecoxib (standard COX2 Inhibitor) & -8.2 \\
\hline
\end{tabular}

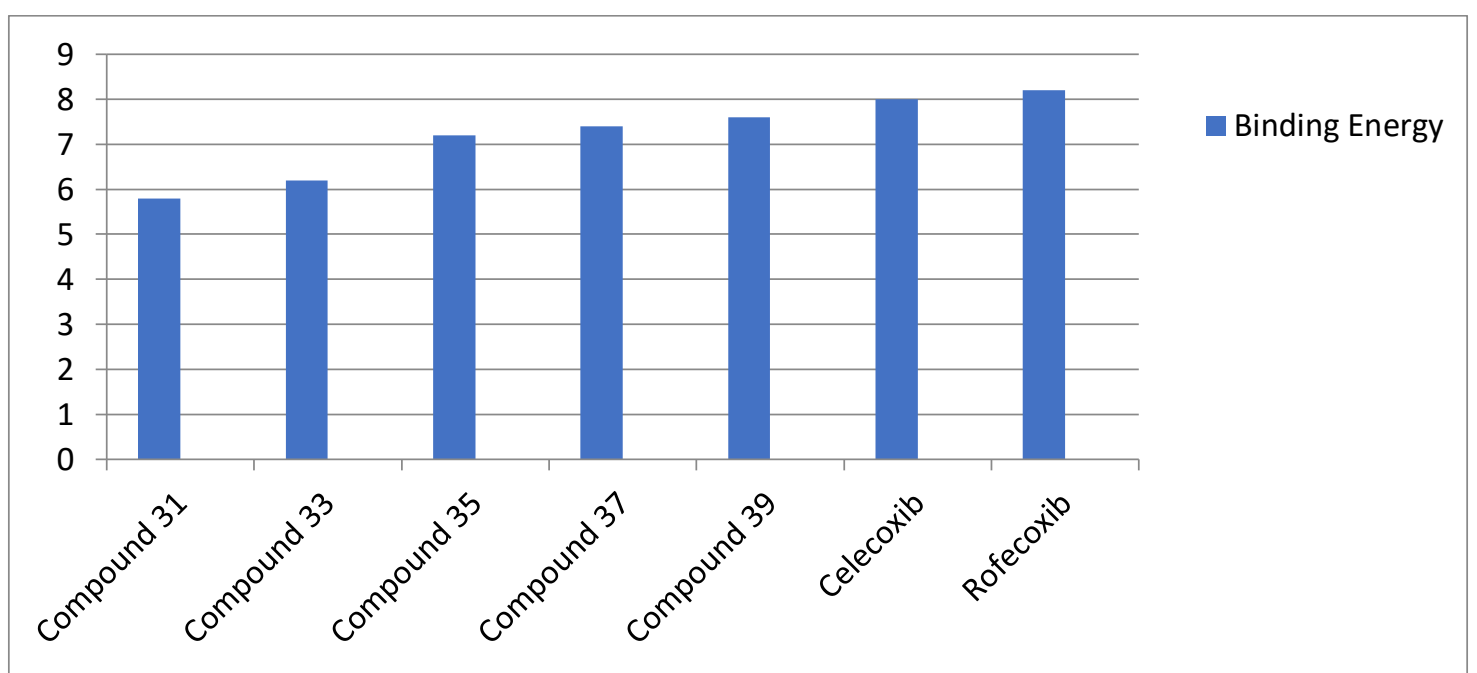

Figure 25: A chart comparing the binding energies of the synthesized compounds and the standard inhibitory drugs for COX2, celecoxib and rofecoxib respectively.

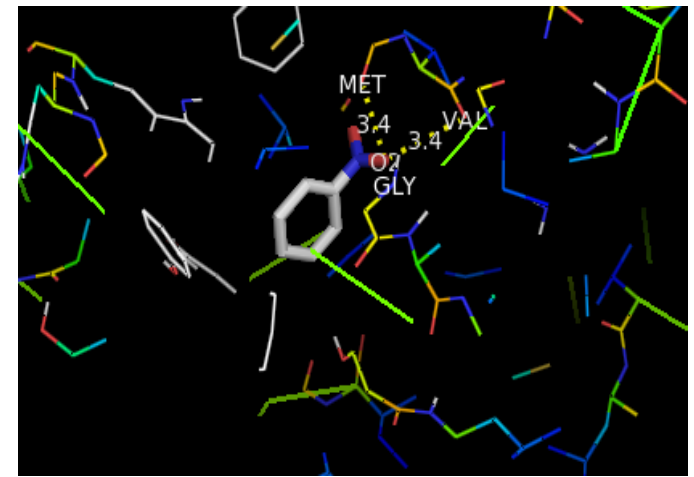

Figure 26: Binding mode of $1 \mathrm{CVU}-31$

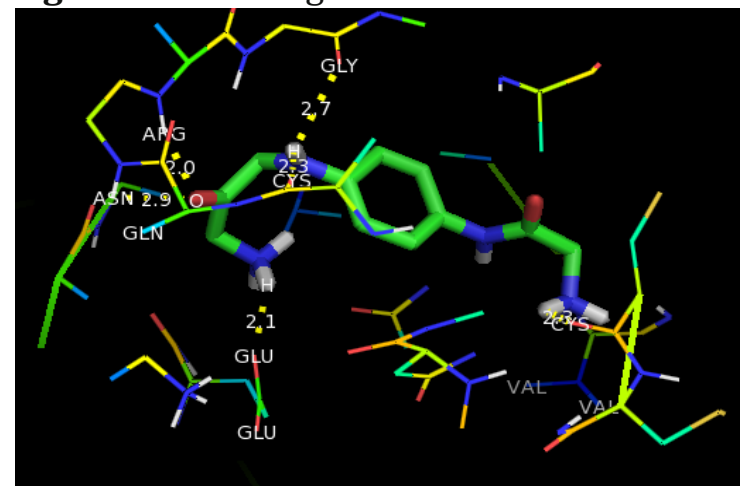

Figure 25: Binding mode of 1CVU - 35

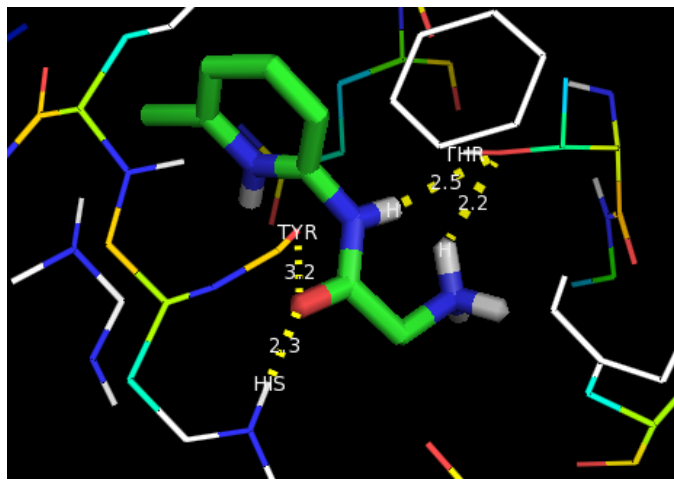

Figure 27: Binding mode of 1CVU-33

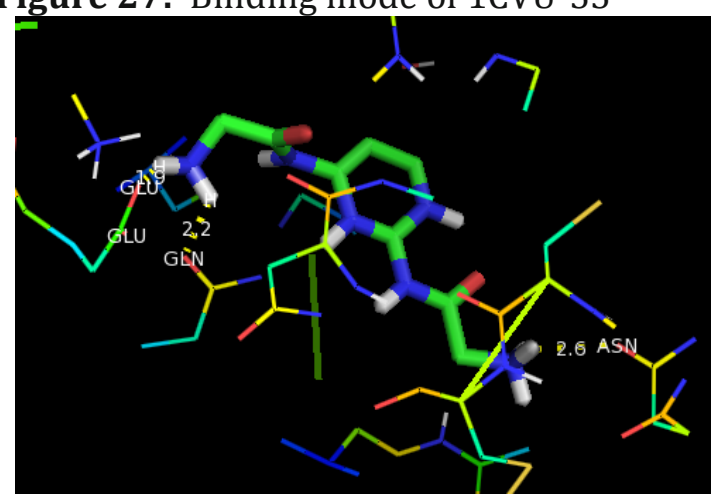

Figure 26: Binding mode of 1CVU - 37 

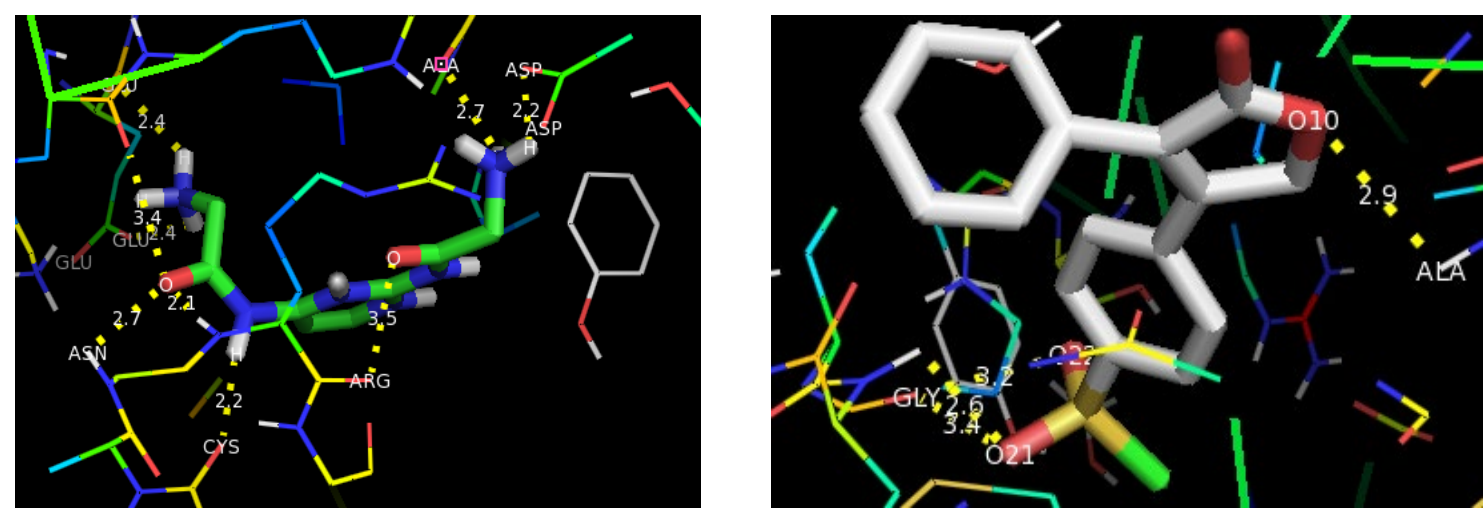

Figure 27: Binding mode of 1CVU-39 Figure 28: Binding mode of 1CVU-Rofecoxib

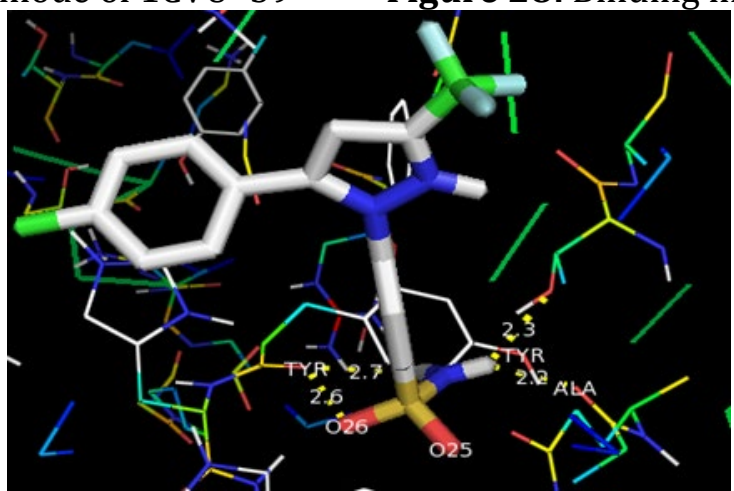

Figure 29: Binding mode of 1CVU-Celecoxib

\section{CONCLUSION}

Five new derivatives of ethyl glycinate bearing carboxamide pharmacophores have been synthesized and characterized in this work. All the compounds showed appreciable binding energies ranging from - 5.8 to -7.6 $\mathrm{kcal} / \mathrm{mol}$ with target protein, 1CVU. Compound showed the highest binding energy of $7.6 \mathrm{kcal} / \mathrm{mol}$. Although the binding energies values were not as high as that of the standard drugs used, these novel compounds could be used as starting materials for the synthesis of drugs that can inhibit COX2 enzyme responsible for causing inflammation in the body.

\section{SOURCES OF FUNDING}

This research received no specific grant from any funding agency in the public, commercial, or not-for-profit sectors.

\section{CONFLICT OF INTEREST}

The author have declared that no competing interests exist.

\section{ACKNOWLEDGMENT}

None.

\section{REFERENCES}

[1] Young VR (1994). "Adult amino acid requirements: the case for a major revision in current recommendations" J. Nutr. 124 (8 Suppl): 1517-1523. doi:10.1093/jn/124. 
Synthesis and Preliminary Molecular Docking Studies of Novel Ethyl-glycinate Amide Derivatives

[2] Dietary Reference Intakes: The Essential Guide to Nutrient Requirements Archived 5 July 2014 at the Way back Machine. Institute of Medicine's Food and Nutrition Board. usda.gov.

[3] W. Wang, Z. Wu, Z. Dai, Y. Yang, J. Wang, and G. Wu, (2013) "Glycine metabolism in animals and humans: implications for nutrition and health," Amino Acids, vol. 45 (3), 463-477.

[4] Wu G (2009) "Amino acids: metabolism, functions, and nutrition", Amino Acids" 37,1-17

[5] Darling PB, Dunn M, Sarwar G et al (1999) “Threonine kinetics in preterm infants fed their mothers' milk or formula with various ratios of whey to casein". American Journal of ClinicalNutrition, 69,105-114

[6] Jackson AA (1991) "The glycine story”. European Journal of Clinical Nutrition 45, 59-65

[7] Melendez-Hevia E, De Paz-Lugo P, Cornish-Bowden A et al (2009) "A weak link in metabolism: the metabolic capacity for glycine biosynthesis does not satisfy the need for collagen synthesis". Journal of Bioscience 34, 853-872

[8] Rezaei R, Wang WW, Wu ZL et al (2013) "Biochemical and physiological bases for utilization of dietary amino acids by young pigs". Journal of Animal Science Biotechnology 4 (7).

[9] R. Senthilkumar and N. Nalini, (2004) "Glycine modulates lipids and lipoproteins levels in rats with alcohol induced liver injury," Internet Journal of Pharmacology, 2 (2), 1-12.

[10] Zeb and S. U. Rahman, (2017) "Protective effects of dietary glycine and glutamic acid toward the toxic effects of oxidized mustard oil in rabbits," Food Function.,8 (1), 429-436.

[11] P. A. Abello, T. G. Buchman, and G. B. Bulkley, (1994) "Shock and multiple organ failure," Advances of Experimental Medicine andBiology, 366 (2), 253-268.

[12] M. Yin, R. T. Currin, X.-X. Peng, H. E. Mekeel, R. Schoonhoven, and J. J. Lemasters, (2002) “Carolina rinse solution minimizes kidney injury and improves graft function and survival after prolonged cold ischemia," Transplantation, 73 (9), 1410-1420.

[13] R. M. Lewis, K. M. Godfrey, A. A. Jackson, I. T. Cameron, and M. A. Hanson, (2005) "Low serine hydroxymethyl transferase activity in the human placenta has important implications

[14] IUPAC, Compendium of Chemical Terminology, 2nd ed. (the "Gold Book") (1997). Online corrected version: (2006-) "esters". doi:10.1351/goldbook.E0221

[15] Montalbetti, Christian A. G. N.; Falque, Virginie (2005). "Amide bond formation and peptide coupling". Tetrahedron. 61 (46): 10827-10852. Doi:10.1016/j.tet.2005.08.031.

[16] Smith, Michael B.; March, Jerry (2007), Advanced Organic Chemistry: Reactions, Mechanisms, and Structure (6th ed.), New York: Wiley-Interscience, ISBN 978-0-471-72091-1

[17] Mohamed I. Hegab, Abdel-Samee M. Abdel- Fattah, Nabil M. Yousef (2007), "Synthesis, X-ray structure and Pharmacological activity of some 6,6-disubstituted chromeno[4,3-b] and chromeno-[3,4-c]-quinolines; Archiv der Pharmazie, Chemistry in Life Sciences 340(8), 396-399.

[18] Nadeem Siddiqui, ShamsherAlam, Waquar Ahsan (2008), "Synthesis, anticonvulsant and toxicity evaluation of 2-(1H-indol-3-yl) Acetyl-N- (substituted phenyl) hydrazine carbothioamides and their related heterocyclic derivatives",ActaPharma. 58(3), 445-454.

[19] Galewicz-Walesa K. and Pachuta-Stec A. (2003), "The synthesis and properties of N-substituted amides of 1(5-methylthio-1, 2, 4-triazol-3-yl) - cyclohexane-2-carboxylic acid", Medical Academy in Lublin, 12(9), 118125.

[20] Graybill, T. L, Ross, M. J.; Gauvin, B. R, Gregory, J. S, Harris, A. L, Ator, M. A, Rinker, J. M, Dolle, R. E, (1992)., "Bioorganic Medicinal Chemistry Letter". Journal of Biological Sciences, 12(1), 1375-1380.

[21] Mihaelamoise, ValeriuSunel, LenutaProfire, Marcel Popa, Catalina Lionte (2008), "Synthesis and antimicrobial activity of some new (sulfonamidophenyl)-amide derivatives of N-(4- nitrobenzoyl)-Phenylalanine”. Journal of Pharmaceutical Sciences. 23(19), 113-121.

[22] Andre Warnecke, IdunaFichtner, Gretel Sab, Felix Kratz (2007), "Synthesis, Cleavage Profile and antitumor efficacy of an Albumin- Binding Prodrug of Methotrexate that is cleaved by Plasmin and Cathepsine B", Archiv der Pharmazie, Chemistry in Life Sciences, 340(8), 12-25

[23] Ledmicer D. and Mitschen L.A. (1980), "The organic drug synthesis", John Wiley and Sons, (2) 248, 226-233.

[24] Delegado J. N. and Remers W.A. (2004), "Test book of organic medicinal and pharmaceutical chemistry", Wilson and GisvoldsLippin. Catt. Raven Philadelphia, 204 (2), 15-68.

[25] Surrender Kumar, D.K. Tyagi and Arun Gupta (2010), "synthesis and evaluation of amide prodrugs of diclofenac" Journal of Pharmaceutical Science and Research. 2 (6), 369-375. 
[26] Kristina E. Furse, Derek A. Pratt, Ned A. Porter,and Terry P. Lybrand (2006)Molecular Dynamics Simulations of Arachidonic Acid Complexes with COX-1 and COX-2, Insights into Equilibrium Behavior; Biochemistry. 2006 March 14; 45(10): 3189-3205.

[27] Liu J, Seibold SA, Rieke CJ, Song I, Cukier RI, Smith WL (June 2007). "Prostaglandin endoperoxide H synthases: peroxidase hydroperoxide specificity and cyclooxygenase activation". The Journal of Biological Chemistry. 282 (25): 18233-44. doi:

[28] Högestätt ED, Jönsson BA, Ermund A, Andersson DA, Björk H, Alexander JP, Cravatt BF, Basbaum AI, Zygmunt PM (September 2005). "Conversion of acetaminophen to the bioactive N-acylphenolamine AM404 via fatty acid amide hydrolase-dependent arachidonic acid conjugation in the nervous system". The Journal of Biological Chemistry. 280 (36): 31405-12. Doi:10.1074/jbc.

[29] Masferrer JL, Zweifel BS, Manning PT, Hauser SD, Leahy KM, Smith WG, Isakson PC, Seibert K (1994). Selective inhibition of inducible cyclooxygenase-2 in vivo is anti-inflammatory and non-ulcerogenic. Proc. Natl. Acad. Sci. 91:3228-3232.

[30] Solomon DH, Glynn RJ, Levin R, Avorn J (2002). Nonsteriodal anti-inflammatory drug use and acute myocardial infarction. Arch. Intern. Med.162: 1099-1104.

[31] FitzGerald GA. Coxibs and cardiovascular disease. N. Engl. J. Med. 2004; 351:1709-1711.

[32] Emil Fischer, Arthur Speier (1895). "Darstellung der Ester". ChemischeBerichte. 28 (3): 3252-3258. Doi:10.1002/cber.189502803176.

[33] Jiabo Li and Yaowu Sha (2008), "A convenient synthesis of amino acid methyl esters". Journal of Biological Sciences. 13(2), 12-17.

[34] PDB: 1CQE; Picot D, Loll PJ, Garavito RM (January 1994). "The X-ray crystal structure of the membrane protein prostaglandin H2 synthase-1". Nature. 367 (6460): 243-9. doi:10.1038/367243a0.

[35] PDB: 6COX; Kurumbail RG, Stevens AM, Gierse JK, McDonald JJ, Stegeman RA, Pak JY, Gildehaus D, Miyashiro JM, Penning TD, Seibert K, Isakson PC, Stallings WC (1996). "Structural basis for selective inhibition of cyclooxygenase-2 by anti-inflammatory agents". Nature. 384 (6610): 644-8. Doi:10.1038/384644a0. 